\title{
A Lost Cause? The Cause for the Canonization of King James II (Invited Commentary)
}

\author{
ANDREW STARKIE
}

"W hen we venerate St. Edward [the Confessor] we venerate a failure.”1 Ronald Knox's assessment of this last English king of his dynasty is a reminder that the Christian cult of the saints is more concerned about things eternal than it is with things temporal. Nevertheless, for that very reason, it has important consequences for this present world. Examination must be made into the manner of life and (more important) death of the candidate for sainthood, if he or she is to be (as saints are) held up as an exemplar of Christian living. Once declared a saint, the gravity of immortality attracts future generations of devotees to petition this once frail human being, now a courtier of heaven, a powerful intercessor before the throne of the Almighty.

While Edward the Confessor has been successfully "raised to the altars," two other English kings have been acclaimed as saints at one time but, despite having begun the required legal process, have not had their cult authenticated by the Catholic Church, and their "cause" appears to be dormant. The first of these, Henry VI, was promoted in Henry VII's reign but fell by the wayside during Henry VIII's, after the king disowned papal authority. There was an attempt to revive the cause in the late 1950s, as a result of correspondence in the Catholic press; the cause was even the subject of a leader article as well as several letters in The Times in 1972. ${ }^{2}$ More recently, the Catholic press has taken notice of that other English (and Scottish and Irish) king who was at one time acclaimed a saint, and whose cause appears not only lost but long forgotten-James II. ${ }^{3}$

James was educated in the faith of the Church of England, for adherence to which (he understood) his father had been martyred. His early life was overshadowed by civil war, confinement, and exile. The experience of exile had, however, exposed him to a breadth of European Catholic culture. He recounted that while in Flanders he was advised by a nun to pray each day that if "he was not in the right way, [God] would bring him to it." Not least among the Catholic influences upon James was his mother, Henrietta Maria, whose own Catholic faith was very strong. The exact date of James's conversion to the Catholic faith is uncertain, though it probably dates from between 1669 and 1672 (from which time he refused to attend any services of the Church of England). It was prompted (with that of his wife, Anne Hyde) by reading Peter Heylyn's history of the English Reformation-written, ironically, as a defense of the Church of England, though critical of the desecration that characterized the Reformation and sympathetic to the medieval Catholicism that it supplanted. ${ }^{4}$

James's conversion to the Catholic faith fiercely divided each of his three kingdoms, threatening to rekindle the embers of the Civil War. The political divisions that characterized

1. Philip Caraman, ed., Occasional Sermons of Ronald A. Knox (London: Burns and Oats, 1960), 26

2. Ralph A. Griffiths, The Reign of King Henry VI (Berkeley: University of California Press, 1981), 1; see also http://www.henrysixth.com/?page_id=19.

3. Charles Coulombe, “The Forgotten Canonisation Cause of King James II,” Catholic Herald, 5 March 2019, https://catholicherald.co.uk/commentandblogs/2019/03/05/the-forgotten-canonisation-cause-of-kingjames-ii/.

4. Geoffrey Scott, "The Court as a Centre of Catholicism," in A Court in Exile: The Stuarts in France, 16891718, ed. Edward Corp (Cambridge: Cambridge University Press, 2004), 235-56, at 241; Peter Heylyn, Ecclesia Restaurata (London, printed for H. Twyford [et al.], 1661). 
English society for over a century were in immediate response to his conversion. Those who opposed his succession to the throne were labeled (as a term of abuse) "Whigs"; those who supported it were similarly labeled "Tories."

His brief reign saw the flowering of a native Catholic culture that had lain dormant since the Elizabethan state had all but destroyed it. Catholic Mass was celebrated publicly. Friars walked the streets of London, and the streets of the university towns, in their habits. Catholic works appeared in print without fear of the censor, and they provoked vigorous religious controversy with defenders of the Church of England. James's visit to the ancient shrine of St. Winefride in Holywell, Flintshire, in 1686 with his second wife, Mary of Modena, to pray for a son and heir, resurrected a tradition of royal pilgrimages that reached back to Henry V's thanksgiving for the victory at Agincourt and beyond. When the prayers of St. Winefride were answered, the prospect of a succession of Catholicism and popular monarchy ("popery" and "slavery") led a fearful Protestant aristocracy to resort to arms.

Although becoming a Catholic defined James’s life, and his place in British history, James's Catholicism was in some ways not typically Catholic. As Hilaire Belloc once noted (in a perceptive study), James "had not the gaiety of the Faith. . . . He had not the tenderness of it." ${ }^{5}$ Although, while duke of York, James appeared conscientiously untroubled by his pursuit of mistresses (Charles II famously jested that his brother's unattractive mistresses were given him by his Jesuit confessor as a penance), there was already an austerity in his spiritual temperament that would later find a home while in exile at Saint Germain in the Abbey of La Trappe.

There is little in James II's life before his usurpation by William of Orange in 1688 and his exile in Saint Germain en Laye that would warrant the claim of sainthood. After 1688, James devoted himself to penitence and piety. The polemical Whig bishop Gilbert Burnet stands at the head of a long tradition of English historiography in which James's penitence after 1688 appears to be a morbid reaction to his political failure, rather than evidence of heroic virtue. ${ }^{6}$ James II's devotional life in exile looks less eccentric, however, taken within the context of European counterreformation Catholicism.

The idea that suffering was a providential means of expiating sin was a normal part of mainstream Catholic thought in the seventeenth century. It gave a redemptive quality to

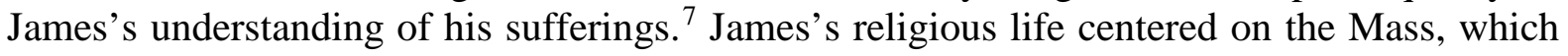
he heard twice a day; he received Holy Communion twice a week and participated in the church's official prayers each day. He was a member of a popular confraternity Bona Mors (Happy Death), which encouraged members to live well by having an awareness of the fragility of life. ${ }^{8}$ The Jesuits were a strong influence on his devotional life- -something he shared with Mary of Modena - as, too, was the Visitation Convent at Chaillot in Paris, which had been founded by St. Francis de Sales. James continually read from Francis de Sales's popular works, Treatise on the Love of God and Introduction to the Devout Life, which emphasized practical Christian living and the holiness of the lay vocation. ${ }^{9}$

It was, however, the Abbey of La Trappe, a place of monastic austerity, that became James's spiritual home. It had been reformed by the abbot, Armand Jean de Rancé, who became something of a spiritual guide to James. Rancé had himself experienced a spiritual conversion, which led him to emphasize the need for manual labor as a penitential element of the monastic life. This enthusiasm was not everywhere well received, and Rancé was unjustly accused of

5. Hilaire Belloc, James the Second (London: Faber \& Faber, 1934), 66.

6. Scott, "The Court as a Centre of Catholicism,” 237; see, e.g., John Miller, James II: A Study in Kingship (London: Methuen, 1989), 234-35.

7. B. and M. Cottret, "La sainteté de Jaques II, ou les miracles d'un roi d'funt," in L'autre exil: Les Jacobites en France au début du XVIIIe siècle, ed. Edward T. Corp (Montpellier: Presses du Languedoc, 1993), 79-106; thanks to Fr Armand de Mallory for help with French.

8. Scott, "The Court as a Centre of Catholicism," 245-46.

9. Scott, "The Court as a Centre of Catholicism," 247-50. 
Jansenism by his enemies. ${ }^{10}$ Despite the polarization of French Catholicism in the public controversy of this era, James does not appear to have had any difficulty in holding together Jesuit, Salesian, and Trappist influences in his own spiritual life. In a letter to Rancé, James confessed, "Til I was with you I did not enjoy that contempt of the world which now I am sencible of." "It was by his patience in his exile, his suffering, and, finally, his death in 1701, that James inspired the cult that would lead to calls for his beatification-the first stage on the road to canonization, or recognition as a saint by the Catholic Church.

Canonization is one of those points at which popular devotion and ecclesiastical authority meet. In Catholic teaching, the soul, separated from the body by death, experiences an immediate judgment. If the soul has not been saved by God's grace, it is consigned to hell (or, if not deserving of hell, "limbo"); if it has reached perfection (for example, through the witness of martyrdom), it is admitted immediately to heaven, to the beatific vision of God; if it is saved but not perfect, it must be purified in purgatory. If a soul is in heaven, then that person is a saint. All canonized saints are in heaven, but not all those in heaven are canonized saints, and it is presumed that many inhabitants of heaven are unknown and unrecognized. ${ }^{12}$

Popular devotion from the earliest Christian centuries has sought the intercession of the saints, for example, by making pilgrimage to the relics of the martyrs, and especially by seeking miraculous healing. The cult of a saint would be promoted by making images or by writing the life of the saint. If genuine, this cult was understood in Catholic theology to be the work of God, helping people on earth through the example and intercession of the saints in heaven. However, from very early in its history, bishops saw the need to regulate the cult of the saints, in order to prevent the faithful from seeking the help of spurious, fictional, heretical, or scandalous "saints." Local bishops therefore asserted the right to determine by "beatification" the cult of the saints within their own dioceses. Since about the tenth century, with the centralization of church authority, the papacy asserted its right to determine by "canonization" which saints might be allowed a cult throughout the Catholic Church, and eventually this papal authority extended to "beatification" as well (so that "beatification" became a step on the way to "canonization"). Canon law developed to assess the testimony of witnesses and to determine the genuineness of the miraculous healings that were necessary to demonstrate that the saint was indeed in heaven, and able to intercede powerfully before God. ${ }^{13}$

By the eighteenth century a body constituted by the pope known as the Congregation of Rites was responsible for regulating the process of both beatification and canonization. In practice it functioned as a brake on the enthusiasms of popular cults, maintaining a rule that fifty years must have elapsed after a person's death before canonization, and there were relatively few canonizations in the seventeenth and early eighteenth centuries. ${ }^{14}$

The cult of James II, which was evident almost immediately upon his death in 1701, drew on an English tradition of devotion to sacred kingship, notably in the cults of Charles I and Edward the Confessor. ${ }^{15}$ Indeed, it has been argued that devotion to James II "after his death, springs rather more from the Anglican tradition of devotion to the Glorious Royal Martyr Charles I, than from the reputation of James II's sanctity within a Catholic ambience during

10. See A. J. Krailsheimer, Armand-Jean de Rancé, Abbot of La Trappe: His Influence in the Cloister and the World (Oxford: Clarendon Press, 1974).

11. J. S. Clarke, The Life of James the Second King of England, 2 vols. (1816), 2:614.

12. The Feast of All Saints (1 November) recognizes the unknown character of many of the saints. Catholics hold that canonization means that the person is indeed in heaven; however, it is still disputed in what sense canonization is an infallible act of the pope.

13. See Eric W. Kemp, Canonization and Authority in the Western Church (Oxford: Oxford University Press, 1948).

14. John Callow, King in Exile, James II: Warrior, King and Saint, 1689-1701 (Stroud: Sutton Publishing, 2004), 390; Callow notes only fifty-five canonizations between 1588 and 1767.

15. Geoffrey Scott, "Sacredness of Majesty": The English Benedictines and the Cult of King James II, Royal Stuart Papers, vol. 23 (Huntingdon: Royal Stuart Society, 1984). 
his last few years in exile.” ${ }^{16}$ Much was made of the fact that the king died at three o'clock in the afternoon on a Friday, the time and day of Christ's death on the cross, and that his illness was first evident when he fainted in the chapel on Good Friday. ${ }^{17}$

James's body was taken to the English Benedictines' church in Paris, where the prior spoke of receiving "the joyful relics of a most Holy Confessor, perhaps even a Revered Martyr." ${ }^{18}$ He was described at his funeral as "a victim for his Church and his Religion." ${ }^{19}$ The funerary chapel became a place of pilgrimage, and there were many reports of healings. On 15 June 1702 Cardinal de Noailles, archbishop of Paris, asked Joachim de la Chétardie "to examine ye Truth of ye King's miracles . . . to serve for his Canonization at Rome.” From the large number of testimonies, de la Chétardie verified nineteen miracles as authentic. Both the English Benedictines in Paris and the Visitation nuns at Chaillot compiled accounts of miracles on behalf of the widowed queen. In one account, an Ursuline nun recounted a cure brought about through a piece of cloth that had been dipped in James's blood while he was being embalmed, testimony that echoed the accounts of similar relics taken following the beheading of Charles I. ${ }^{20}$

During the following years, the cause appeared to have lost impetus, but it was renewed in 1734, when the English Benedictine Abbot Southcott drew up "memorials" of the king's life from eye witnesses, for submission to the Congregation of Rites in Rome. In January 1735 the cause was ready to be transmitted to Rome. When Benedict XIV was elected pope in 1740 the cause was still proceeding, but after that it appears to have quietly lapsed. ${ }^{21}$

Canonization retains its importance, both for its spiritual purpose and for its wider symbolism, for it seems to give the last word on whether the saint is truly among the sheep or the goats, which in our contemporary dialectical political discourse is an invitation to be outraged. $^{22}$ James II's political troubles may not, in our own age, seem compelling reasons for his elevation to the altars. His penitence for his waywardness, however, and his devotion to things eternal, have all the hallmarks of sincerity about them, and a perennial relevance.

The House of Stuart spent several decades of the eighteenth century and considerable resources pursuing the beatification of James II without success. In more recent years one offspring of that dynasty has, however, been beatified. On 25 January 2014 the pope recognized Blessed Maria Cristina of Savoy (1812-36) among the Blessed. She was a direct descendent of James II's sister, Henrietta. Her feast day, 31 January, falls the day after the Anglican commemoration of Charles I.

16. Scott, Sacredness of Majesty, 2.

17. An exact account of the sickness and death of the Late King James II . . (London, 1701), 3.

18. Scott, Sacredness of Majesty, 2.

19. Scott, "The Court as a Centre of Catholicism,” 244.

20. Scott, Sacredness of Majesty, 3-4.

21. Scott, Sacredness of Majesty, 9-10; Benedict XIV was, incidentally, the author of an authoritative work on canonization: see Kemp, Canonization, 148-49.

22. See, for example, press comment on proposals for the beatification of Queen Isabella of Spain: e.g., Kenneth L. Woodward, "Isabella Is No Saint,” New York Times, 6 April 1991; for the sheep and the goats, see Matthew 25. 